\title{
Molecular Identification of Oesophagostomum spp. from Himalayan Grey Langur
}

\author{
Bhinsara Dharmesh Kumar ${ }^{\text {** }}$, M. Sankar ${ }^{1}$, R. Kumar ${ }^{1}$, A. Kumar ${ }^{1}$, P. Kadian ${ }^{1}$, \\ Bhawana Kushwaha ${ }^{2}$, B.C. Parthasarathi ${ }^{2}$, Ravi Kumar Khare ${ }^{1}$ and D. Chandra ${ }^{2}$ \\ ${ }^{1}$ Indian Veterinary Research Institute, Mukteswar Campus, Nainital-263138, \\ Uttarakhand, India \\ ${ }^{2}$ Indian Veterinary Research Institute, Izatnagar Campus, Bareilly- 243122, \\ Uttar Pradesh, India \\ *Corresponding author
}

\section{Keywords}

Oesophagostomum

spp., Himalayan

grey langur

Article Info

Accepted:

04 February 2018

Available Online:

10 March 2018

\section{A B S T R A C T}

Nodular worm, Oesophagostomum spp. are most pathogenic strongyles of ruminants, pigs, non-human primates and other mammals. Transmission of Oesophagostomum parasite between humans and non-human primates are not frequent, however, it may occurs in areas where habitats are overlapped. The present study was carried out to explore the seasonal prevalence of strongyle infection in Himalayan grey langurs (Semnopithecus ajax) of Mid Himalayan range, Kumaon region, Uttarakhand over the period of six years (April 2011 to March 2017) with special emphasize on Oesophagostomum spp. The occurrence and intensity of infection was ascertained by qualitative and quantitative methods and results were compared with PCR method. The egg per gram (EPG) was determined by McMaster method from salt floatation positive samples. DNA was extracted from microscopy positive samples $(n=50)$ and negative faecal samples $(n=100)$; subsequently the DNA was subjected for amplification of Internal Transcribed Spacer-2 (ITS-2) of ribosomal DNA (rDNA) of Oesophagostomum spp. The overall incidence of strongyle infection based on microscopy was $12.82 \%$ (104/811). The mean EPG was varied between 171- 528 \pm 39 . The genus specific PCR amplified single, 333bp Oesophgostomum spp fragment from genomic DNA. The PCR method amplified all the microscopy positive faecal samples, additionally it also revealed 29 positive out of 100 samples which were negative by microscopy. The overall prevalence of Oesophgostomum spp by PCR was $52.66 \%$ (79/150), which indicates the higher sensitivity of the test than microscopy. The intensity of infection was more in monsoon and autumn months (from mid-August to November) and less positive cases were observed from winter and springs. The information gathered in this study revealed that Oesophagostomum is a common strongyles infecting Himalayan Grey Langur and it has zoonotic transmission potential.

\section{Introduction}

India is rich in unique and diverse wildlife. A number of factors threaten the existence of wild animals in this country, including parasitic diseases arising from gastrointestinal nematodiasis. The exchange of disease is a concern for wildlife conservation both outside 
and inside the boundaries of parks and reserves. The presence of tourists and other personals has created a situation that may facilitate disease transmission between humans, livestock and wildlife (Simonetti, 1995; Butynski and Kalina, 1999). Anthropogenic disturbance is frequently speculated to influence the nature of parasite infections in wildlife (Greger, 2007) and concern over the potential of zoonotic disease transmission has grown with increasing human encroachment and population size (Chomel et al., 2007; Goldberg et al., 2007). The forested edges of primate habitat, especially those that border humanized landscapes, i.e., areas of intense human use such as villages or crop fields, provide opportunities for humans and non-human primates to come into close proximity.

Nodular worm infections, caused by Oesophagostomum spp are common in human and wild primates; mostly asymptomatic and clinical signs have only been recorded in captive settings (Stewart and Gasbarre, 1989). Studies have suggested that there was transmission of nodular worm among nonhuman primates and humans and thus primates poised a health risk to people or vice versa (Krief et al., 2010; Ghai et al., 2014). Among Oesophagostomum genus, $O$. bifurcum, $O$. stephanostomum, and $O$. aculeatum, are important due to their potential to infect humans (Ghai et al., 2014). The ingestion of food with contaminated parasitic eggs and their $3^{\text {rd }}$ stage larvae can cause infection (Soulsby, 1982). The major consequence of infection is development of nodules in the intestine due to development of third stage larva. The infection causes abdominal pain, anorexia, diarrhea and cachexia, and occasional death from peritonitis and intestinal occlusion (Soulsby, 1982; Taylor et al., 2015). The eggs/infective third stage (L3) obtained after coproculture can be identified only to the genus level (Gasser et al., 2009). Langurs are common non-human primates in mid Himalayas; they feed on a variety of plant materials, periodic evacuation of parasites from digestive tract will be a common feature (Joseph et al., 1999). Therefore, detailed survey is essential to understand the implication of gastrointestinal nematodiasis in langurs of mid Himalayan region. As of now, very little or no population data exist for nematode infections of free living langurs of mid Himalayan region. The paucity of data has necessitated this study with primary objective to provide data on gastrointestinal strongyles of langurs with special emphasize on Oesophagostomum spp of the cited region.

\section{Materials and Methods}

\section{Sample collection}

The present study was carried out on free range langurs in the Kumaon ranges of Himalaya $\left(29^{\circ} 28^{\prime} \mathrm{N}\right.$ and $79^{\circ} 39^{\prime} \mathrm{E}, 7500$ feet above mean sea level). A total of 811 relatively freshly voided faecal samples of langurs were collected over the period of six years (April 2011 to March 2017) in all seasons [spring (March to June), monsoon (July to September), autumn (October to November) and winter (December to February)]. The samples were collected randomly from both sex and different age group of langurs. The samples were collected non-invasively in labeled containers from the forest and immediately transferred to laboratory. Since identity of the animals was not possible, samples from the same animals may be collected more than one times. Therefore, the number of sample sizes was probably more than the number of animals.

\section{Parasite examination}

The occurrence and intensity of infection was determined by qualitative (salt floatation) method. The positive samples were subjected 
for modified McMaster quantitative method for quantification of parasitic eggs (Soulsby, 1982; Fowler, 1986). The microscopy positive $(n=50)$ and negative faecal samples $(n=100)$ were subjected for DNA isolation using QIAamp DNA stool mini kit (Qiagen, Germany) following manufacturer's instructions. The genomic DNA was subsequently used for polymerase chain reaction (PCR) to identify Oesophagostumum spp.

\section{Polymerase chain reaction}

The primers for internal transcribed spacer -2 (ITS-2) with upstream flanking region about 117 bp of ribosomal DNA (rDNA) were selfdesigned using published sequences of Oesophagostomum spp (Oeso forward: 5' TCG ACT AGC TTC AGC GAT G 3'; Oeso reverse: 5'CCA AAG CAT TCT TAG TCG CT 3'). PCR was carried out in thin wall PCR tubes in $25 \mu \mathrm{l}$ reaction volume. The PCR mixture consisted of $12 \mathrm{ng}$ of DNA template, 12 pmoles of each primer (Oeso forward and Oeso reverse), $1.5 \mathrm{mM} \mathrm{MgCl}_{2}, 200 \mu \mathrm{M}$ of each dNTPs, and $2.5 \mu \mathrm{l}$ of $10 \mathrm{x}$ Taq DNA polymerase buffer and $1 \mathrm{U}$ of Taq DNA polymerase (Fermentas, Germany). The volume of the reaction was made up to $25 \mu \mathrm{l}$ with autoclaved milli-Q water. Polymerase chain reaction was performed with the following conditions. Initial denaturation at $94^{\circ} \mathrm{C}$ for two minutes was followed by 36 cycles each at $94^{\circ} \mathrm{C}$ for $30 \mathrm{~s}, 53^{\circ} \mathrm{C}$ for $30 \mathrm{~s}$ and $72^{\circ} \mathrm{C}$ for $30 \mathrm{~s}$. This was followed by $5 \mathrm{~min}$ final extension at $72^{\circ} \mathrm{C}$. The amplicons were electrophoresed using $2 \%$ agarose gel and the DNA migration and resolution pattern was examined by UV transillumination technique and the picture was documented by photography.

Statistical analyses were performed using the Chi test for analysis (Snedecor and Cochran 1994).

\section{Results and Discussion}

The overall incidence of strongyle infection based on qualitative egg analysis on 811 samples was $12.82 \%(n=104)$ (Table 1$)$. The mean egg per gram (EPG) was varied between 171- 528 \pm 39 . The EPG was started appearing from Mid-April and maintained in various ranges up to November.

The peak EPG was observed during and after monsoon. Effect of the year on the prevalence of strongyle or Oesophgostomum spp was found to be non-significant. It was observed that the prevalence of the strongyle or Oesophgostomum spp was fairly comparable for all the six years of the study.

However, effect of season on the prevalence of strongyles was found to be highly significant $(p=0.00)$ (Table 2). Prevalence was almost negligible $(2.5 \%)$ in the winter months (December to February), followed by spring (March to June) (5.64\%) by microscopy. Significantly higher $(21.22 \%)$ prevalence of strongyle spp was observed in the monsoon i.e. from July and September followed by in autumn $(9.38 \%)$ i.e. October to November.

The genus specific PCR amplification on ITS2 specifically amplified single, Oesophgostomum spp fragment from genomic DNA isolated from positive and negative faecal samples by microscopy.

The amplicon size was 333bp (Figures 1 and 2), which including ITS-2 (216 bp) and flanking region of about 117 bp upstream to ITS-2. The specific PCR amplified all the microscopy positive faecal samples, which indicating positive detection of Oesophgostomum spp.

The PCR also showed 29 out of 100 samples, which were negative by microscopy (Table 3 ). The overall prevalence of Oesophgostomum spp by PCR was $52.66 \%$ (79/150). 
Table.1 Prevalence of strongyle infection in langurs by microscopy

\begin{tabular}{|l|}
\hline Year (April to March) \\
\hline $2011-2012$ \\
\hline $2012-2013$ \\
\hline $2013-2014$ \\
\hline $2014-2015$ \\
\hline $2015-2016$ \\
\hline $2016-2017$ \\
\hline Total \\
\hline
\end{tabular}

\begin{tabular}{|c|c|}
\hline No of samples screened & $\begin{array}{l}\text { Percentage positive for Strongyle spp } \\
\text { in qualitative method }\end{array}$ \\
\hline 194 & $11.34 \%(n=22)$ \\
\hline 186 & $13.97 \%(n=26)$ \\
\hline 168 & $13.69 \%(n=23)$ \\
\hline 93 & $12.9 \%(n=12)$ \\
\hline 71 & $13.18 \%(n=12)$ \\
\hline 811 & $11.39 \%(n=09)$ \\
\hline
\end{tabular}

Table.2 Seasons wise prevalence of Strongyle spp by microscopy

\begin{tabular}{|l|c|c|}
$\begin{array}{l}\text { Year } \\
\text { April to March) }\end{array}$ & No of samples screened & $\begin{array}{l}\text { Percentage positive for Strongyle spp } \\
\text { in qualitative method }\end{array}$ \\
\hline Spring & 195 & $05.64 \%(n=11)$ \\
\hline Monsoon & 344 & $21.22 \%(n=73)^{* *}$ \\
\hline Autumn & 192 & $09.38 \%(n=18)^{* *}$ \\
\hline Winter & 80 & $02.5 \%(n=02)$ \\
\hline
\end{tabular}

Table.3 Results of PCR amplification for Oesophgostomum spp

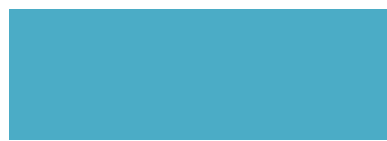

Microscopy positive

Random microscopy negative samples

\begin{tabular}{|c|c|c|}
\hline $\begin{array}{l}\text { No of samples } \\
\text { screened }\end{array}$ & $\begin{array}{l}\text { Percentage positive for } \\
\text { Strongyle spp in } \\
\text { qualitative method }\end{array}$ & $\begin{array}{l}\text { Percentage positive for } \\
\text { Oesophgostomum spp in } \\
\text { PCR }\end{array}$ \\
\hline 50 & 50 & 50 \\
\hline 100 & 0 & 29 \\
\hline
\end{tabular}

Fig.1 and 2 PCR amplification of ITS-2 and upstream flanking region about 117 bp of O. stephanostomum

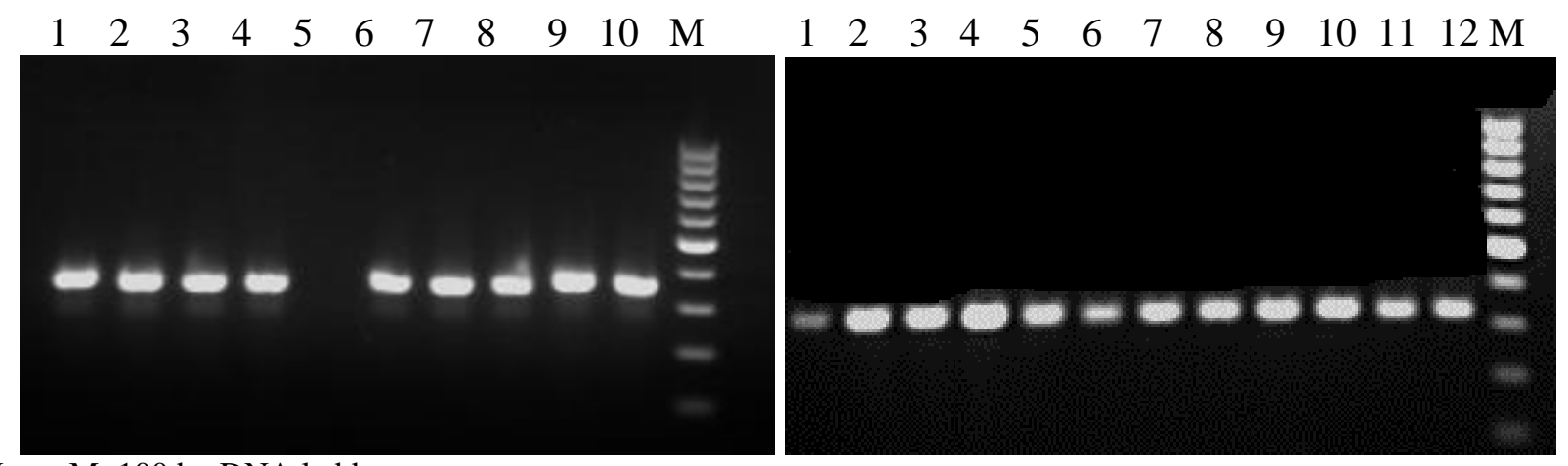

Lane M: 100 bp DNA ladder

Lane 1-4 and 6-10 in left gel is Oesophgostomum ITS-2, 333bp

Lane 5 - in left gel negative control

Lane 1-12 in right gel is Oesophgostomum ITS-2, 333bp 
The present study mainly focused on prevalence of Oesophgostomum spp in langurs by specific PCR method, therefore no attempt was made for specific diagnosis for other strongyle species. There are also chances of mixed infections in langurs.

In the present study, we determined strongyles infection by microscopy and nodular worm infection by PCR in langurs in Kumaon region of Uttarakhand. The results revealed that first evidence of Oesophagostomum spp infection present in langurs of mid-Himalayas in Kumaon region by molecular method. The microscopy results revealed the prevalence of strongyles were lowest in the winter months followed by spring that might be due to hypobiosis of larvae in the host thus, less number of infective larvae in the pasture. However, significantly higher prevalence of strongyles was observed in the monsoon and post monsoon seasons. This pattern can be assigned to variation in the rainfall and temperature in the weather that favors the spurt of infective larvae in the environment (Soulsby, 1982; Taylor et al., 2015). Limited number of study has been conducted in langurs pertaining to gastrointestinal strongyles. Earlier studies reported that strongyles, in which Oesophagostomum spp are common in Nilgiris langurs of Tamil Nadu (Rajendran et al., 2004; Tiwari et al., 2017). O. bifurcum, O. stephanostomum and $O$. aculeatum are most important species of non-primates and also human (Stewert and Gasberre, 1989; Gasser et al., 2009; Ghai et al., 2014). The present study a genus specific PCR was standardized to identify Oesophagostomum spp and compared with microscopy using same samples. The results of microscopy indicated that this test significantly under estimated the infection and in other hand PCR method proved more sensitive. As many as 29 negative cases out of 100 by microscopy were detected
Oesophagostomum spp positive by PCR. Ghai et al., (2014) also applied microscopy and PCR for diagnosis of different Oesophagostomum spp of primates including human and found that PCR is more sensitive than microscopy. Previous studies reported Oesophagostomum spp infection in primates from Uganda (Gillespie et al., 2004, 2005) and its potential zoonotic importance (Ghai et al., 2014; Cibot et al., 2015). The study concluded that Oesophagostomum spp are common but highly neglected and under estimated infection in non-human primates of India. The langurs of mid Himalays move freely in human dwelling and also share same habitats with human pose severe zoonotic risk. The present study findings enlighten further to determine this infection in other primates of the country in details, due to increased proximity between non-human primates and humans. The further study is warranted on rDNA gene sequencing and phylogentic analysis of Oesophagostomum spp from non-human primates and human to ascertain zoonotic importance.

\section{Acknowledgement}

The authors are highly acknowledged the Indian Council of Agricultural Research (ICAR) for funding through network programme on gastrointestinal parasitism and Director, Indian Veterinary Research Institute for providing facilities for research.

\section{References}

Butynski, T. M. and Kalina, J. 1999. Gorilla tourism: a critical look. In Conservation of biological resources. Pp. 280-300.

Chomel, B. B., Belotto, A. and Meslin, F. X. 2007. Wildlife, exotic pets and emerging zoonoses. Emerg Infect Diseases. 13: 6-11.

Cibot, M., Guillot, J., Lafosse, S., Bon, C., Seguya, A. and Krief, S. 2015. Nodular Worm Infections in Wild Non-human Primates and Humans Living in the Sebitoli 
Area (Kibale National Park, Uganda): Do High Spatial Proximity Favor Zoonotic Transmission? PLoS Negl Trop Dis. 9(10): 4133.

Fowler, M.E., 1986. Zoo and Wild animal medicine. 2nd ed. W.B.Saunders Company, Philadelphia. pp: 700-701.

Gasser, R. B., de Gruijter, J. M., and Polderman, A. M., 2009. The utility of molecular methods for elucidating primate-pathogen relationships the Oesophagostomum bifurcum example. In M. A. Huffman \& C. A. Chapman (Eds.), Primate parasite ecology: the dynamics and study of hostparasite relationships. Cambridge: Cambridge University Press. pp: 47-62

Ghai, R.R., Chapman, CA., Omeja, PA., Jonathan Davies, T and Goldberg TL. 2014. Nodule worm infection in humans and wild primates in Uganda: cryptic species in a newly identified region of human transmission. PLoS Negl Trop Dis. 8: 2641.

Gillespie, T.R., Greiner EC. and Chapman CA. 2004. Gastrointestinal parasites of the guenons of western Uganda. J Parasitol 90: 1356-1360.

Gillespie, T.R., Greiner, EC. and Chapman, CA. 2005 Gastrointestinal parasites of the colobus monkeys of Uganda. J Parasitol. 91: 569573.

Goldberg, T.L., Gillespie, T. R., Rwego, I. B., Wheeler, E., Estoff, E. L. and Chapman, C. A. 2007. Patterns of gastrointestinal bacterial exchange between chimpanzees and humans involved in research and tourism in western Uganda. Biol. Conserv. 135: 511-517.

Greger, M. 2007. The human/animal interface: emergence and resurgence of zoonotic infectious diseases. Crit Rev Microbiol. 33: 243-299.
Joseph, G.K., Pallai, K.M., Xavier, F., Michael, B. and Amrithraj, M. 1999. A coprological survey of parasites in two endangered primates of silent valley National park, Kerala. Indian Forester. 125(10): 1027-1030.

Krief, S., Vermeulen, B., Lafosse, S., Kasenene, J.M., Nieguitsila, A. and Berthelemy, $\mathbf{M}$. 2010. Nodular worm infection in wild chimpanzees in Western Uganda: a risk for human health? PLoS Negl Trop Dis. 4: 630.

Rajendran, S., Saseendran, P.C., Subramanian, H. and Yuvaraj, N. 2004. A survey of gastrointestinal parasitic infection in Nilgiri Langur (Semnopithecus johnii) at KalakkadMundanthurai Tiger Reserve, Tamil Nadu. Zoo's Print Journal. 19 (4): 1454.

Simonetti, J.A. 1995. Wildlife conservation outside parks is a disease-mediated task. Conserv. Biol. 9: 454-456.

Snedecor GW. and Cochran WG. (1994). Statistical Methods, $8^{\text {th }}$ ed., (Lowa University Press, Lowa, U.S.A.).

Soulsby, E. J. L., 1982. Helminths, Arthropods and Protozoa of Domesticated Animals. 6th edition, Bailliere Tindall, London: Pp. 56-58.

Stewart, T. and Gasbarre, L. 1989. The veterinary importance of nodular worms (Oesophagostomum spp.). Parasitol Today 5: 209-213.

Taylor, M. A., Coop, R. L. and Wall, R. L. 2015. Veterinary Parasitology, 4th Edition, Wiley Publications. United States.

Tiwari, S., Reddy, D. M., Muthulingam Pradheeps., Sreenivasamurthy, G. S. and Umapathy. G. 2017. Prevalence and cooccurrence of gastrointestinal parasites in Nilgiri Langur (Trachypithecus johnii) of fragmented landscape in Anamalai Hills, Western Ghats, India. Current Science. 113(11): 2194-2200.

\section{How to cite this article:}

Bhinsara Dharmesh Kumar, M. Sankar, R. Kumar, A. Kumar, P. Kadian, Bhawana Kushwaha, B.C. Parthasarathi, Ravi Kumar Khare and Chandra, D. 2018. Molecular Identification of Oesophagostomum spp. from Himalayan Grey Langur. Int.J.Curr.Microbiol.App.Sci. 7(03): 146-151. doi: https://doi.org/10.20546/ijcmas.2018.703.017 